\title{
Voting with Your Brain or Heart, Hands or Feet? An Enquiry in the Microeconomics of Intra- and Inter- National Political Competition
}

\author{
Matei-Alexandru APĂVĂLOAEI \\ The Bucharest University of Economic Studies, Bucharest, Romania \\ matei.apavaloaei@rei.ase.ro \\ Octavian-Dragomir JORA \\ The Bucharest University of Economic Studies, Bucharest, Romania \\ octavian.jora@rei.ase.ro \\ Mihaela IACOB \\ The Bucharest University of Economic Studies, Bucharest, Romania \\ mihaela.iacob@fin.ase.ro
}

\begin{abstract}
This paper is an interdisciplinary analysis of the benefits and limits of political competition. We start from the economic theory of monopoly and extend its implications on matters concerning political action. If the state is defined as the institution that holds the monopoly on coercion over a given territory, are the democratic selection process (internal political competition) and the possibility open to an economic agent to leave for more economically free jurisdictions (international political competition) enough to temper its reach? By referring to the inherent limits that plague collective action, voter rational ignorance, and the possibility of redistributing benefits and incumbent decision-maker collaboration when it comes to trading votes, we argue that democratic competition cannot be considered an effective restraint against political discretion. Because of this, we consider that international political competition can offer better protection against political action. However, even the possibility of voting with one's feet or observing the political milieu in another territory become manageable if political decision-makers decide to collude at the international level. Also, emigration is an economically costly and psychologically exacting decision that ultimately implies choosing between two state-controlled jurisdictions. Therefore, even the choice of voting with one's feet is a second-best solution that, in practice, might not prove to be an effective restraint on the state's monopoly discretion.
\end{abstract}

Keywords: state, political competition, monopoly, institutional competition, praxeology

\section{Introduction}

In the most profound understanding of the concept, it is a dangerous metaphor to consider the citizen's position vis-à-vis the state as equivalent to that in which the consumer finds himself in the context of the market. An act of consumption involves private property, choice, and catallactic scarcity (Mahoney, 2002). Also, as it consists of an act of voluntary exchange, we can deduce that it must always be considered an ex ante utility enhancing decision, from which both partners stand to gain (Rothbard, 2011). In the context of voluntary exchange, the distribution of income between individuals, and between the owners of the factors of production that went into producing the good that is traded stems from the preferences and utility enjoyed by the consumer. In the confines of the market economy, all prices are therefore determined by the consumers' preferences, including the prices of the factors of production, which are imputed from the result to the means employed into making it 
(Menger, 2007). Who receives what and which position in the division of labor that each individual should occupy is determined by a special kind of vote - i.e., a ballot of the market -, continuously held and where every cent does count (Mises, 2008). It is edifying to contrast all this with what is implied by the concept of "citizenship".

In the "statehood" context, private property is replaced by "fiat property" (Hoppe, 2011), which means that the state, i.e., the agent that was allegedly "delegated" - by means of the (overstated) democratic tools - by the citizens to represent their interests (Casey, 2012), decides the extent to which one may maintain and control his/her private property. Therefore, the decision concerning what and where gets to be produced is no longer in the hands of producers and no longer reflects the exclusive choice of consumers. In this case, the state also plays a role when it directs, in the name of its citizens, a good part of these matters - once when it taxes and creates money out of nothing, and then when it decides what to do with these resources (Rothbard, 2009). Market exchange is replaced with the coercive extraction of resources without any meaningful way of determining if the result came anywhere close to the citizens' preferences. Demonstrated preference (Rothbard, 2011) is replaced with passivity, while threats penalize non-compliance. Also, distribution, i.e., the corollary of production and adequately serving the consumer, is replaced by political decisions regarding re-distribution. The market ballot, where the consumer is "sovereign", is replaced by sharing up the output according to other ("higher") rationales.

With this target in mind, in the following, we propose a two-pronged approach. We will first address the most poignant issue pertaining to those public and common goods that the state monopolizes. The question we will raise is this: Taking into account that the state is the entity holding the monopoly for supplying a particular good, is it warranted to consider that such a scenario is exempt from the common problems that neoclassical economic theory associates with a market where a single seller prevails? (Or putting it otherwise: is state control a sufficient guarantee for avoiding a smaller than optimum output, a higher price and lower quality of goods and services than those prevailing in a competitive market?) Then, we will address a potential retort to the answer we provide to the first question. Namely, we will argue that the problems posed by a state-controlled monopoly cannot be swept under the rug by pointing to the "competition" that exists on the political scene. We are going to argue that the democratic decision-making process is plagued by numerous perverse incentives that make internal ("democratic") political competition one very ineffective mechanism in disciplining political decision-makers and leading them toward a coherent management of state-supplied "public"/"common" goods.

The second part of our investigation is going to analyze the incentives that political decision-makers face when acting in an international context, i.e., when there is more than one jurisdiction between which citizens may choose to move to, and to which to look to. Or, as Vaubel (2008) names these two instances of political competition: "voting with one's feet" and "yardstick competition". We will point out that, although international political competition is a relatively more efficient instrument in disciplining political decision-makers, it too represents only a second-best solution. This is because it ultimately means that citizens have to choose between different states, i.e., institutions of the same kind, and therefore they do not get to select between genuine alternatives, but between different degrees of state interventionism. A genuinely different option would involve a private system of governance. In this scenario, individuals would be free to choose between various voluntary communities. 
In order to join such an association, each person would have to accept a contractual agreement that explicitly stipulated the rights and obligations that each individual has to accept if joining a specific community. If such a scenario is considered "utopian," this is so only in the sense that states outlaw it, not that it is absurd / unnatural.

\section{A note on the methodology}

PICBE $\mid 891$

This analysis is done under the praxeological reign of the Austrian School of economics and political science. There is a fruitful compatibility between "Austrian" value subjectivism and "libertarian" jus naturalism, this being one of the more interesting pairings in modern social science, despite its eccentricity from mainstream academic and policy discourse.

This "paradigm choice" was made due to the analytical comfort displayed by praxeology - the qualitative logic of human action: verbal reasoning in terms of teleological causality, logical inferences of theory from basic axioms of human action, needing neither empirical validation nor econometric modeling, though being crucial in decrypting history.

This is about the philosophical, epistemological sense of methodology. As far as the practical, operational sense of methodology employed in this particular research, it will comprise a critical, creative, (de)constructive review of the building blocks of theoretical, conceptual literature in this domain, from a comparative, qualitative perspective.

\section{The perverse incentives run by intra-national political contest}

Classical liberalism qua political program exuded optimism over the potential of democracy, which was considered a superior system to the princely rule of the anciene régime (Mises, 2002). Democracy meant that the decision-makers held their position as a result of a popular vote, while elections were considered an effective method of weeding out and identifying the most appropriate character for the job.

This selection process implied that those individuals that wanted to hold public office had to cater to the wishes of the electorate. Furthermore, classical liberals considered that this system had the potential to bring about a more peaceful order, both in matters concerning international relations, and in those concerning internal strife, as periodic elections could ensure the uneventful transition of power to those that represented the majority of the voters.

Despite this optimism, democracy's track-record is a long distance away from what the classical liberals expected, in matters concerning both the pursuit of the electorate's best interests and in paving the way toward a more peaceful world (Hoppe, 2001). But in this paper we will investigate only if both intra-national and inter-national political competition represent adequate solutions for keeping political decision-makers attuned to the very interests of the beneficiaries of public/common goods.

It is true that internal political competition does put some checks on the powers that be, just as classical liberal authors thought. Unfortunately, the electorate's control over its delegates is an imperfect mechanism, prone to manipulation and buy-offs. It is because of this that any hope that intra-national political competition might be considered an appropriate lever for ensuring the appropriate supply of public and common goods must be relegated. Therefore, we are going to focus only on the incentive problems that democracy brings about.

\section{The political comparative advantage}


The economics literature provides a harsh verdict when it comes to assessing a democratic system's performance. For starters, we may invoke the theory of comparative advantage and its corollary that each individual tends to specialize in those activities/professions where they have a relative edge over their competitors. In political science terms, this is equivalent to Pareto's, Mosca's, and Michels's iron law of oligarchy. Political power is going to be held by the few; what we cannot say is what criteria are going to be considered relevant when it comes to selecting the individuals that make up this minority.

\section{The rationally ignorant voter}

Leadership could be delegated to honest and diligent individuals, but it is just as likely (and economic theory argues that it is more likely so) that political control will be seized by those members that hold sway over the electorate's imagination and beliefs. In other words, the criteria that are taken into account by the voters when it comes to selecting their representatives may very well be questionable, and, as the theory of the rationally ignorant voter argues, the incentives are aligned in such a way as to make irresponsible voting decisions more attractive (Downs, 1957; Schumpeter, 2013).

\section{The lack of an objective criterion of performance}

The idea that it is rational for voters not to waste time and resources on exploring what politician is the best choice gains additional weight when coupled with another insight from Rothbard (2009) and Schumpeter (2013). Both authors explain that in the absence of an objective and easy to grasp criterion of performance, like the "profit and loss" test in market setting, voters have no meaningful way of evaluating the performance of decision-makers or the sensibleness of their programs.

An objective evaluation of the effectiveness of policymakers when it comes to keeping with their publicly assumed promises becomes a daunting task even for the public-spirited and conscientious voter. This leaves citizens even more predisposed to listen to propaganda and fall prey to unfounded ideologies (Mises, 2011). In some aggravating circumstances, these problems may lead to a race to the bottom, which culminates with the worse getting on top (Hayek, 2001; Hoppe, 2014a).

\section{The logic of collective action}

If the use of the ballot box seems to be a weaker than expected method of controlling decision-makers, the odds seem to be stacked against dissent and direct opposition as well. Even when politicians lose the support of the electorate, it is hard to successfully organize the masses to actively oppose the powers that be. As Olson (1982; 1993) argues, it is inherent in the logic of collective action for a large group to find it more difficult than a small one to effectively organize. Also, the minority that makes up the ruling elite receives concentrated benefits from holding on to power, while the entire population bears the costs.

Therefore, the minority will not only find it easier to organize and eliminate the free rider problem, but it will also be incentivized to put up a stronger fight against the majority that wants them out. Most likely, unless a radical change in ideology occurs in the society, the majority of the discontent will remain passive, while the pockets of active resistance will have to confront alone the well-organized apparatus of repression. This means that the class of the 
"governed" gets sensibly more numerous than the class of the "governors" (Boétie, 2008; Mises, 2008), but the incentives are against political upheaval (Tullock, 1971).

\section{The bestowment of privileges}

Internal political competition is also undermined by the possibility open to politicians to bestow privileges on various social categories or producers. "Pork barrel", as such practices are known, becomes possible especially in an institutional context where votes can be exchanged between elected politicians. "Log-rolling", the process through which members of the legislature trade votes with their peers in exchange for support in the future, makes it possible for politicians to pass acts of legislation that allow them to gain favor with voters (Buchanan \& Tullock, 1962) and thus blur the line between net taxpayers and net tax consumers (Rothbard, 2000).

All of the incentives mentioned above allow us to explain why internal political competition does not lead to rapid change that penalizes decision-makers when they fail to adequately supply the goods and services over which the state holds a monopoly. Indeed, it seems that the democratic process tends to allow inefficiency to perpetuate itself, thus adding another perverse incentive to those already contained by the state's monopoly over the supply of public and common goods.

\section{The real limits that circumscribe intra-national political action}

Even if the incentive structure faced by political decision-makers seems to favor the status quo and allow them to remain disconnected from the needs of the consumers of public and common goods, we can deduce from the nature of political action that politicians still have to take into account two limits that transcend the incentive problems we have analyzed above (Apăvăloaei, 2015; 2018). These two limits are: 1 . the exhaustion of the reserve fund, or the objective limit, and 2 . the ideological limit we have already alluded to above and to which we may also refer to as the subjective limit.

\section{The exhaustion of the reserve fund}

This first one is a limit that is derived from the coercive nature of political action (Mises, 2008). Unlike economic cooperation, which is grounded on appropriation, production, and exchange based on contractual agreement - what Oppenheimer (1975) called the "economic means" of accumulating wealth -, political action employs the implicit or explicit use of force to extract resources and live off the efforts of another individual. In other words, the individual employing political action is like a parasite. All his activities can come only after economic action has been carried out, and can be continued only as long as it does not extract too much as to stifle private initiative or consume the capital needed for carrying on production. In a popular phrasing, it is so politically important never to "kill the goose that lays the golden eggs".

\section{The ideological limit}

The second limit that political action faces is the ideological limit, or what we may call the subjective limit. If a government, no matter how generous its tax base is, loses its legitimacy - i.e., the vast majority of the electorate considers it oppressive and decides to oppose it actively -, then the game is over for the elite that controls the state. Therefore, it is imperative 
that the government does everything it can to prevent such a scenario: it can control education, the media, or it could bestow generous gifts on its supporters. But all these measures cannot determine the beliefs of the subjects - i.e., the ideology they embrace. While economists can talk about incentives and their effect on peoples' choices, they take preferences as data. The ideological limit is the equivalent of a changing in the data; it is the result of the human person's "free will".

PICBE $\mid 894$

These two limits - objective and subjective - necessarily exist. They are a direct consequence of the nature of political action. All the perverse incentives that we have already touched upon act in the sense of delaying the very moment in which at least one of these two limits is reached. At the same time, it is in the interest of political decision-makers to tread prudently and do all that is in their power, also taking advantage of these incentives, not to reach the limits. Hence, the key behind political entrepreneurship is maximizing the quantity of extracted resources without exhausting (or taking a too large chunk out of) the subsistence fund or without consuming the legitimacy that the institution they administer is credited with by the vast majority.

Thus, it can be argued that any instance that makes political decision-makers face these two limits sooner is a step in the direction of narrowing the sphere of political action and enlarging that of private property and cooperation through voluntary association. If a smaller quantity of resources is used or redistributed by the state, there is a larger available stock of resources left in private hands, which can be allocated through the market or can finance various civil society initiatives. This means that some of the common or public goods that are commonly provided by the government will be substituted for a larger private offer. The price system and private donations will replace the coercively financed and irrationally supplied goods and services.

\section{The confines on political action in an international playground}

One such circumstance that limits the scope of political action is represented by the fact that, currently, humanity does not live under a world government. Because there are a multitude of national states that coexist on the world stage, we can deduce that on top of the objective and subjective limits there is a third one that policymakers must take into account. This third limit, which we will call the external limit, is represented by international political competition. As coexisting political jurisdictions are independent of one another, it means that their subjects are now in a position to put to their advantage the differences that emerge from the diversity of political decisions adopted in each territory. The very fact that the citizens of a state can now choose to "vote with their feet" and can observe the lifestyles afforded by foreigners and compare their welfare with theirs put a strain on political action (Hoppe, 1993; Vaubel, 2008). Therefore, international political competition acts as a catalyst, accelerating the speed with which the reserve fund is exhausted and the pace at which legitimacy is lost.

For instance, if authorities in a country impose a higher tax on incomes than that existing in another territory, capital and labour (the mobile factors of production) will tend to flee from the jurisdiction where political action extracts relatively more resources. This will lead to a more rapid exhaustion of the reserve fund. At the same time, the relative impoverishment of the more highly taxed territory, corroborated with the possibility open to the citizens living there to compare their welfare with that of foreigners, will lead to a more 
rapid loss of legitimacy than would have been the case if such a comparison would not have been possible. That is not to say that part of the extracted resources, besides that fraction that is directly consumed by the ruling class, will not be redistributed in the attempts to buy the loyalty of the relevant stakeholders and muddle the public debate. But, at the end of the day, the territory under consideration will have more individuals living on welfare provisions and a larger supply of not very urgently needed public goods, while the relatively freer area will have greater prosperity, i.e., a more abundant and varied supply of consumers' goods. Also, the less encroached society will be a relatively more peaceful and civilized place, as fewer people would be in a position to live off the efforts of third parties and continuously fight for control over the largest possible amount of undeserved resources.

In this context, we can understand why political decision-makers frown upon any territory trying to obtain its independence and why they favor political centralization and uniformization (i.e., "political integration", as well), although this means that certain prerogatives associated with national sovereignty have to be ceded (Apăvăloaei, 2015; 2016).

Between two bad options - one state versus several coexisting/competing states - the latter seems the more benign solution for the citizen/consumer, as it hinders to a somewhat greater extent the reach of political action. When considering all the perverse incentives that plague internal (democratic) political competition - viz., the inherent difficulties in monitoring, assessing, and making an informed choice during elections --, we can understand why international political competition is a more stringent constraint on political action. This is not to say that the differences in welfare cannot be explained away through false propaganda. Indeed, examples such as "the West is rich because it exploited its colonies" or "the US might be materially rich, but it is spiritually corrupt and plagued by crime and drugs" are frequently heard. Also, nationalist sentiments can also be used to serve the political agenda. Be that as it may, all we argue is that international political competition offers a more effective method of assessing the results brought about by different levels of employing political action than what would be possible for the ordinary voter to grasp only by following the political debate that goes on in his country. Ceteris paribus, in the context of international political competition, we expect that public/common goods will tend to be more adequately supplied by the state. But again, this is only a difference in degree, not in kind.

\section{Some thick margins for the international political competition}

After presenting the advantages of international political competition, this section has the ingrate task of bringing things back into context. Unfortunately, not even this kind of check on political discretion represents an efficient lever for making decision-makers fully accountable for their action and disciplining their supply of public and common goods.

Critics of the status quo are usually admonished along the following lines: Taking into account that we now live in an age of labour and capital mobility, no one keeps you from leaving. Of course, there are still some restrictions, but one can emigrate if he does not like the conditions in his home country. "Ubi bene, ibi patria" seems to be the catchphrase.

Indeed, part of this view of things is correct. If people are free to move to other territories and have access to information regarding the results of other political arrangements, the government they currently live under faces an additional challenge. But 
there are some bounds that the political competition argument faces - four being sketched hereinafter.

\section{International political "cartelization"}

First, political competition is vulnerable to collusion, which takes the form of international political cooperation (Apăvăloaei, 2014). For instance, if states adopt a uniform rate of taxation and similar regulations, they will eliminate the possibility of arbitration between jurisdictions that their citizens initially enjoyed. Unlike the setting of a standard on the market or the decision to opt out of such a standard by any producer if he thinks that a different technology will bring him more profit, political unification is not necessarily aimed at satisfying consumers' needs. Regardless of the intent behind such a political decision, one thing is certain: it limits the number of available options that the citizen may choose from. Political decision-makers are incentivized to push for the adoption of such a standardized approach over the broadest possible area, as it is costlier to move to another country than to a different county of the same nation. This is because of the greater distance that needs to be travelled, or the cultural and language differences that may exist. Hence a possible way to limit international mobility is to ensure that the same policies are adopted over a larger territory.

Moreover, unlike market collusion, governments are allowed to formalize their agreement by establishing supranational organizations or by signing formal international agreements. These forms of international political cooperation limit the leeway that any government has when it comes to exiting such an agreement. It also follows that unilateral repudiation of such a deal will be punished as harshly as possible so as to discourage any further attempts to leave the arrangement. And since the costs are externalized, decisionmakers will tend to apply the costliest possible punishment on dissenters. Taking into account that international cooperation can also take the form of joint projects for supplying public or common goods (e.g., transcontinental infrastructure projects, joint management of natural resources, like fisheries, policing of external borders), we can see why the repudiation of a cooperation agreement can be made very difficult for any nation that decides to go its own way. International public and common goods become the jointly acquired assets over which a divorce becomes either too expensive to be concluded or the point of contention that permanently sowers all future interactions.

\section{Psychological costs of migration}

Second, political competition and the possibility to leave a given territory represent secondbest options for any individual. This is because such a departure automatically involves leaving behind all acquaintances and the immovable property that one possesses. Sociological studies (Sampson \& Groves, 1989; Oishi \& Schimmack, 2010) have linked such severance of personal ties with episodes of psychological strife, health issues, and even higher delinquency rates. Therefore, the high personal costs also spill over in external costs, which are bore by the entire community. In addition to these "psychological costs", which by their very nature cannot be quantified, there is also a loss in wealth that a person leaving a territory must accept when he is forced to sell his assets. Thus, "voting with one's feet" is not an easy nor a cheap escape for any citizen even international mobility is not restricted. 
This is one of the great motives for which the obviously inefficient and oppressive regimes do not see a massive outflow of resources overnight. When considering the costs of "voting with one's feet", another thing to be considered is the fact that most public and common goods and services that the state provides are provided only in the territory and for the citizens - i.e., registered taxpayers, that live there. All citizens are in this sense "forced riders", which means that they are forced to contribute regardless of their preferences or plans to leave the country. Usually, such goods and services do not represent a big incentive to remain in the country of origin. Nevertheless, we cannot ignore that the citizen has no residual claim over his already paid contribution and that once he has left the country, he will have to forgo all potential benefits which he might have enjoyed and for which he already paid.

\section{Choosing "between Scylla and Charybdis}

Third, we have to point out that the current institutional alternatives that an individual voting with his feet has to choose between are different members of the same species, as all territories are currently under the control of a state. In other words, it is a choice between Scylla and Charybdis, one that allows individuals to opt for that jurisdiction that extracts the least amount of resources. In our current historical setting, the option not to be ruled over by a state is not offered at all. This means that international political competition remains a compulsory choice, as no individual can opt not to be a citizen of at least one state, or not pay some taxes, or conform to some arbitrary rule. This point can also be viewed through the lenses of opportunity cost. The problem is the following: without a market for polities or public and collective goods, how can a government or a citizen know what the best available set of rules is? How can anyone know what opportunities - i.e., other forms of organization could be possible if any construction outside a state is not allowed?

To drive the point though, we can make a parallel with the optimal decision regarding the maximum speed limit on a road. For example, in Romania, road legislation imposes a 50 $\mathrm{km} / \mathrm{h}$ speed limit inside rural and urban areas. The same limit has remained in force for some years, despite the technological progress that car making has undergone, which allows producers to offer speedier and safer vehicles. From the start, we can see that the choice of modifying the default maximum speed limit faces a trade-off. On the one hand, a higher speed limit means faster traveling, which does not automatically amount to more dangerous driving conditions. On the other hand, maintaining the present speed limit offers more predictability, in the sense that, after all these years, drivers have become accustomed to it. Also, an abatement from the default speed limit can be signaled through billboards in those areas that are deemed safe for speeding. Taking into account that both options have specific benefits and costs, how can any decision-maker select what is "best" for citizens?

\section{Impact over the adoption country}

Fourth, it is not enough to focus on the emigration and the polity that he chooses to leave behind and overlook the impact of his decision on the country he moves to. An inflow of migrants can put a strain on welfare provisions in the host country and on its infrastructure. It is true that migrants usually end up being net contributors to the budgets of the governments where they settle, but we cannot disregard the fact that such calculations take into account only the taxes and incomes that are earned from the moment when a migrant 
enters a new territory. Therefore, such calculations ignore that he is free riding on the infrastructure he finds in that country, although he and his ancestors did not pay for it (Hoppe, 2014b).

This fact would not be problematic in itself, provided that the community he enters could set some rules for selection and would also charge a fee for the use of the infrastructure it gives access to. But the rules are not in themselves up for discussion, nor adaptable to the needs of the citizens residing there. Also, public and common goods are not provided through the market, but are the unilaterally assumed monopoly of the state and are financed through taxes. This means that anyone the state decides to allow inside its borders can free ride and consume the contribution of the "forced riders" - i.e., the taxpayers, already living there. In this context, it comes as no surprise that this situation undermines political competition.

\section{Conclusion (the rather unspoken than utopian solution)}

If we may be permitted the metaphor, in a polycentric arrangement - i.e., in a private property rights based order -, where all communities result after a freely agreed contractual agreement between the inhabitants (not a vaguely assumed "social contract"), those associations that decided to open their gates and accept those outsiders that vote with their feet would probably function along the lines of hotel services providers. They would charge a fee that reflected the entire monetary value of the capital goods that went into providing such services (as most probably they would accept a deferred payment).

Also, they would select their clientele in order to maximize the chances of receiving their due remuneration and in such a fashion as not to disturb its present residents nor chase away potential clients. But under present-day conditions the individuals that were born in the host country and that paid their contributions to the state all their lives have no reason to be accommodating with foreigners. On the contrary, they are heavily incentivized to show hostility towards potential migrants and signal them that they are not welcome to free ride and consume the public and common goods they did not contribute to.

\section{References}

Apăvăloaei, M.A. (2014). An Economic and Political Analysis of Interventionism: The Place of Political Integration. OEconomica, 23(3), 17-28.

Apăvăloaei, M.A. (2015). An Outline of a Praxeological Theory of Politics. Quarterly Journal of Austrian Economics, 18(2), 91-125.

Apăvăloaei, M.A. (2016). A Note Next De-Homogenizing Economic and Political Integration from a Praxeological Perspective. The Review of Social and Economic Issues, 1(3), 5-56.

Apăvăloaei, M.A. (2018). Analiza praxeologică a acțiunii politice și a cooperării politice internaționale: $O$ abordare interdisciplinară la confluența dintre știința economică și știința politică. Bucharest: Editura ASE.

Boétie, E. (2008). The Politics of Obedience: The Discours of Voluntary Servitude. Auburn: Mises Institute.

Buchanan, J. M., \& Tullock, G. (1962). The Calculus of Consents: Logical Foundations of Constitutioned Democracy. Ann Arbor: University of Michigan Press.

Casey, C. (2012). Libertarian Anarchy: Against the State (Think Now). London: Continuum International Publishing Group.

Downs, A. (1957). An Economic Theory of Political Action in a Democracy. Journal of Political Economy, 65(2), 135-150. 
Hayek, H.A. (2001). The Road to Serfdom. London: Routledge.

Hoppe, H.H. (1993). Nationalism and Secession. Retrieved from http://en.liberpedia.org/Nationalism_and Secession.

Hoppe, H.H. (2001). Democracy: The God That Failed. New Brunswick: Transaction Publishers.

Hoppe, H.H. (2011). Entrepreneurship with Fiat Property. Retrieved from http://mises.org/library/entrepreneurship-fiat-property.

PICBE | 899

Hoppe, H.H. (2014a). From Aristocracy to Monarchy to Democracy, A Tale of Moral and Economic Folly and Decay. Auburn: Mises Institute.

Hoppe, H.H. (2014b). A Realistic Libertarianism. Retrieved from https://misesmedia.s3.amazonaws.com/A\%20Realistic\%20Libertarianism.pdf?file=1\&type=document.

Jora, O.D., Apăvăloaei, M.A., and Iacob, M. (2018). Cultural Heritage Markets: Are Traders Traitors? Winners and Losers from Cross-Border Shifts of Historical Artefacts. Management \& Marketing. Challenges for the Knowledge Society, 4(2), 897-912.

Mahoney, D. (2002). Ownership, Scarcity, and Economic Decision Making. Quarterly Journal of Austrian Economics, 5(1), 39-56.

Menger, C. (2007). Principles of Economics. Auburn: Mises Institute.

Mises, L. (2002). Liberalism in the Classical Tradition. Auburn: Mises Institute.

Mises, L. (2008). Human Action: A Treatise on Economics (1 ${ }^{\text {st }}$ ed.). Auburn: Mises Institute.

Mises, L. (2011). Critique of Interventionism. Auburn: Mises Institute.

Oishi, S. and Schimmack, U. (2010). Residential Mobility, Well-Being, and Mortality. Journal of Personality and Social Psychology, 98(6), 980-994.

Olson, M. (1982). The Rise and Decline of Nations: Economic Growth, Stagflation, and Social Rigidities. New Haven and London: Yale University Press.

Olson, M. (1993). Dictatorship, Democracy, and Development. The American Political Science Review, 87(3), 567-576.

Oppenheimer, F. (1975). The State. Its History and Development Viewed Sociologically. New York: Vanguard Press.

Rothbard, M.N. (2000). Egalitarianism as a Revolt Against Nature and Other Essays (2nd ed.). Auburn: Mises Institute.

Rothbard, M.N. (2009). Man, Economy, and the State (with Power and Market) (2nd ed.). Auburn: Mises Institute.

Rothbard, M.N. (2011). Economic Controversies. Auburn: Mises Institute.

Sampson, R., and Groves, B.A. (1989) Community Structure and Crime: Testing SocialDisorganization Theory. The American Journal of Sociology, 94(4), 774-802.

Schumpeter, J.A. (2013). Capitalism, Socialism and Democracy (5 $5^{\text {th }}$ ed.). London: Routledge.

Tullock, G. (1971). The Paradox of Revolution. Public Choice, 11(1), 89-99.

Vaubel, R. (2008). A History of Thought on Institutional Competition. In Bergh, A., ArreguiHöijer, R. (Eds.). Institutional Competition (pp. 29-66). Cheltenham: Elgar.

Wiśniewski, J.B. (2018). The Economics of Law, Order, and Action. London and New York: Routledge. 